\title{
Sampling Rate of Polar Organic Chemical Integrative Sampler (POCIS): Influence Factors and Calibration Methods
}

\author{
Liyang Wang ${ }^{1,2} \mathbb{D}$, Ruixia Liu ${ }^{1,2, *}$, Xiaoling Liu $^{1}$ and Hongjie Gao ${ }^{1}$ \\ 1 State Key Laboratory of Environmental Criteria and Risk Assessment, Chinese Research Academy of \\ Environmental Sciences, Beijing 100012, China; darktee@163.com (L.W.); liuxl@craes.org.cn (X.L.); \\ gaohj@craes.org.cn (H.G.) \\ 2 College of Water Sciences, Beijing Normal University, Beijing 100875, China \\ * Correspondence: liurx@craes.org.cn; Tel.: +86-10-8491-9726-601; Fax: +86-10-8491-7906
}

Received: 28 June 2020; Accepted: 7 August 2020; Published: 11 August 2020

\begin{abstract}
As a passive sampling device, the polar organic chemical integrative sampler (POCIS) has the characteristics of simple operation, safety, and reliability for assessing the occurrence and risk of persistent and emerging trace organic pollutants. The POCIS, allowing for the determination of time-weighted average (TWA) concentration of polar organic chemicals, exhibits good application prospects in aquatic environments. Before deploying the device in water, the sampling rate $\left(R_{S}\right)$, which is a key parameter for characterizing pollutant enrichment, should be determined and calibrated accurately. However, the $R_{S}$ values strongly depend on experimental hydrodynamic conditions. This paper provides an overview of the current situation of the POCIS for environmental monitoring of organic pollutants in an aquatic system. The principle and theory of the POCIS are outlined. In particular, the effect factors such as the ambient conditions, pollutant properties, and device features on the $R_{S}$ are analyzed in detail from aspects of impact dependence and mechanisms. The calibration methods of the $R_{S}$ under laboratory and in situ conditions are summarized. This review offers supplementary information on comprehensive understanding of mechanism and application of the POCIS. Nevertheless, the $R_{S}$ were impacted by a combined effect of solute-sorbent-membrane-solution, and the influence extent of each variable was still unclear. On this basis, the ongoing challenges are proposed for the future application of the POCIS in the actual environment, for instance, the need for this device to be improved in terms of quantitative methods for more accurate measurement of the $R_{s}$.
\end{abstract}

Keywords: passive sampling; POCIS; sampling rate; influence factors; calibration

\section{Introduction}

The development and application of a fast, efficient, and low-cost integrated sampling approach is of great significance for monitoring the concentration and fate of trace pollutants in the water environment, and furthermore for accurately assessing their toxicity and risk. Passive sampling is the developing technique that is based on the flow of pollutants from environmental medium to uptake phase due to chemical potential difference between pollutants [1-4]. On the basis of the principle of permeation or molecular diffusion, pollutants could enter the uptake phase by passive diffusion through a well-defined diffusion barrier or permeation through a membrane, thus achieving the enrichment of target substances in the environment media [5]. Compared to active sampling, the uptake rate of compounds by passive sampling is relatively low, and thus a longer exposure time is needed for sampling in a low-concentration environment, which has a significant advantage, 
allowing the measurement of time-weighted average (TWA) concentration of target pollutants and more comprehensively reflecting the long-term effects of these pollutants [6-9].

Nowadays, many configurations of water passive sampling devices have been proposed for inorganic pollutants, such as diffusive gradient in thin film technique (DGT), peeper (a kind of balanced permeate device), and Chemcatcher $[6,10,11]$, and for organic pollutants, such as polar organic chemical integrative sampler (POCIS), semi-permeable membrane devices (SPMDs), membrane enclosed sorptive coating (MESCO), Chemcatcher, and others [12-16]. The development milestones in the field of passive sampling are shown in Figure $1[10,17]$. These passive sampling devices can be performed in two different accumulation regimes during field exposure: the kinetic linear uptake mode with fast mass transfer rate to the uptake phase, and the equilibrium regime with slower stagnant uptake, described by a partition coefficient of contaminant between the uptake phase and the environmental media [18].

\begin{tabular}{|c|c|c|}
\hline 1987 & $\begin{array}{l}\text { Hydrophilic regenerated cellulose dialysis bag filled with } \\
\mathrm{n} \text {-hexane for the determination of non-polar pollutants }\end{array}$ & . \\
\hline 1990 & First publication on SPMDs & \\
\hline 1991 & First publication on $\mathrm{DET}$ & \\
\hline 1992 & First publication on SLM & \\
\hline 1993 & First publication on PISCES & - Development of \\
\hline 1994 & First publication on DGT & $\begin{array}{l}\text { passive sampler for } \\
\text { monitoring inorganic }\end{array}$ \\
\hline 1995 & Use of passive samplers combined with bioassays & or organic pollutants \\
\hline 1997 & Passive diffusion bag for sampling of $\mathrm{VOC}$ in groundwater & $\mathrm{v}$ \\
\hline 1998 & In situ calibration using PRCs & \\
\hline 1999 & First publication on POCIS & \\
\hline 2000 & First publication on Chemcatcher & \\
\hline 2001 & First publication on MESCO & \\
\hline 2002 & $\begin{array}{l}\text { Concentration distribution of active phosphorus at the } \\
\text { sediment-water interface determined by new two-dimensional } \\
\text { balanced dialysis panel }\end{array}$ & $\begin{array}{l}\text { Application of } \\
\text { passive sampling } \\
\text { technology in }\end{array}$ \\
\hline 2009 & $\begin{array}{l}\text { Concentration of PAHs at the sediment-water interface } \\
\text { determined using LDPE as sorbent }\end{array}$ & $\begin{array}{l}\text { environmental } \\
\text { multiphase interface }\end{array}$ \\
\hline 2010 & $\begin{array}{l}\text { Fluxes of PAHs and PCB at the sediment-water interface } \\
\text { estimated by Chamber }\end{array}$ & \\
\hline 2012 & Concentration of sulfamethoxazole determined by o-DGT & \\
\hline 2014 & $\begin{array}{l}\text { Risk assessment of } \mathrm{ZnO} \text { nanoparticles in water or } \\
\text { sediment by DGT }\end{array}$ & $\begin{array}{l}\text { - Emerging pollutant } \\
\text { monitored by passive }\end{array}$ \\
\hline 2016 & $\begin{array}{l}\text { Determination of marine biotoxins by SPATT combined } \\
\text { with high-resolution mass spectrometry }\end{array}$ & - Application of \\
\hline 2017 & $\begin{array}{l}\text { Toxicity assessment of algal toxin in freshwater and } \\
\text { seawater by SPATT }\end{array}$ & $\begin{array}{l}\text { Integrated approaches, } \\
\text { e.g. sampling- }\end{array}$ \\
\hline 2019 & $\begin{array}{l}\text { Bioavailability of estrogenic compounds from sediment } \\
\text { evaluated by POCIS and Chemcatcher }\end{array}$ & $\begin{array}{l}\text { monitoring-biological/ } \\
\text { toxic effect analysis }\end{array}$ \\
\hline
\end{tabular}

Figure 1. Milestones in the development of passive sampling in aquatic environment (DET: diffusive equilibrium in thin films technique; SLM: supported liquid membrane; PISCES: passive in situ concentration extraction sampler; PRCs: performance reference compounds; LDPE: low-density polyethylene; SPATT: solid phase adsorption toxin tracking bags.).

The POCIS has been identified as an effective passive sampler for qualitative analysis of pesticides, pharmaceuticals, and perfluorinated compounds (PFCs), among others, in surface water, groundwater, and wastewater [8,19-22]. It has the advantages of simple operation, low cost, no power demand, no maintenance requirement for isolation, and enrichment of organic compounds at low concentrations in a water environment. Before application of POCIS for the monitoring of target compounds, it is necessary to determine the sampling rate $\left(R_{s}\right.$, the equivalent volume of water drawn by the sampler per unit time) for each compound of interest, which is the key parameter to deduce the concentrations of pollutant in water from the amount of pollutants accumulated by the sampling device [23]. Obtained $R_{s}$ 
values can be further optimized to determine the average concentration of analytes in the environment so as to decrease the uncertainty of in situ application [18,24-26]. It has been reported that the $R_{S}$ values would not be affected by analyte concentrations in water, however, this is totally dependent on a range of environment factors, such as water turbulence, temperature, salinity, biofouling, physicochemical parameters of water body, and so on [16,27-30]. For example, Yabuki et al. [27] reported that the $R_{s}$ values increased with temperature, flow rate, and $\mathrm{pH}$, while Shi et al. and others [21,31-33] only observed a significant effect of the salinity on uptakes for basic pharmaceuticals. As a matter of fact, these environment conditions are so complex that questions still remain in these aspects as to how the $R_{S}$ values are impacted by environmental factors and how the in situ calibration methods of the $R_{S}$ need to be improved for accurate quantification of target pollutants.

Therefore, the aim of this review is to mainly focus upon on the $R_{s}$ values of the POCIS in relation to its influence factors, such as ambient factors, compound properties, and device features, as well as its calibration method in laboratory and in situ, which would furthermore allow for a comprehensive understanding of the mechanisms and applications related to the POCIS since the device was first reported to measure the hydrophilicity pollutants in 1999 [34].

\section{Theory of the POCIS}

The POCIS, a permeation-based passive sampler, consists of a receiving phase made of solid sorbent sandwiched between two microporous diffusion-limiting membranes [34]. The passive diffusion of pollutants into the POCIS in an aquatic environment can be regarded as a multi-phase mass transfer process. As shown in Figure 2, the analytes firstly transport through the water boundary layer (WBL) from bulk water; then across biofilm, water-filled membrane pores, and the membrane matrix transfer by molecular diffusion; and finally the analytes enter the absorbent phase inside the device [35]. Several mathematical models have been proposed to describe the dynamic process of compound sorption in passive samplers, which have some differences in the composition of models [36]. Most of them are based on simplified common assumptions: the existence of steady (or pseudo-stability) state, isotropic water sampler exchange kinetics, and the linear distribution curve. In those cases, the accumulation of analytes by passive samplers typically follow first-order kinetics (Equation (1)), which is divided into dynamic and equilibrium stages with time [37].

$$
C_{s}(t)=C_{w} K_{m w}\left(1-e^{-k_{e} t}\right)
$$

where $C_{s}(t)$ is the concentration $(\mu \mathrm{g} / \mathrm{g})$ of analyte in the sorbent; $C_{w}$ is the TWA concentration $(\mu \mathrm{g} / \mathrm{L})$ of the analyte in water; $K_{m w}\left(k_{u} / k_{e}\right)$ is the partition constant $(\mathrm{L} / \mathrm{g})$ of analytes in membrane water; $k_{e}$ and $k_{u}$ are the elimination and uptake rate constants $(\mathrm{L} / \mathrm{g} / \mathrm{d})$, respectively; and $t$ is exposure time (days). In the Equation (1), the $k_{e}$ value can be defined as follows [38]:

$$
k_{e}=\frac{R_{s}}{K_{m w} M_{s}}
$$

where $R_{S}$ is the sampling rate $(\mathrm{L} / \mathrm{d}$ or $\mathrm{mL} / \mathrm{d})$ and $M_{S}$ is the mass $(\mathrm{g})$ of sorbent in the POCIS. 


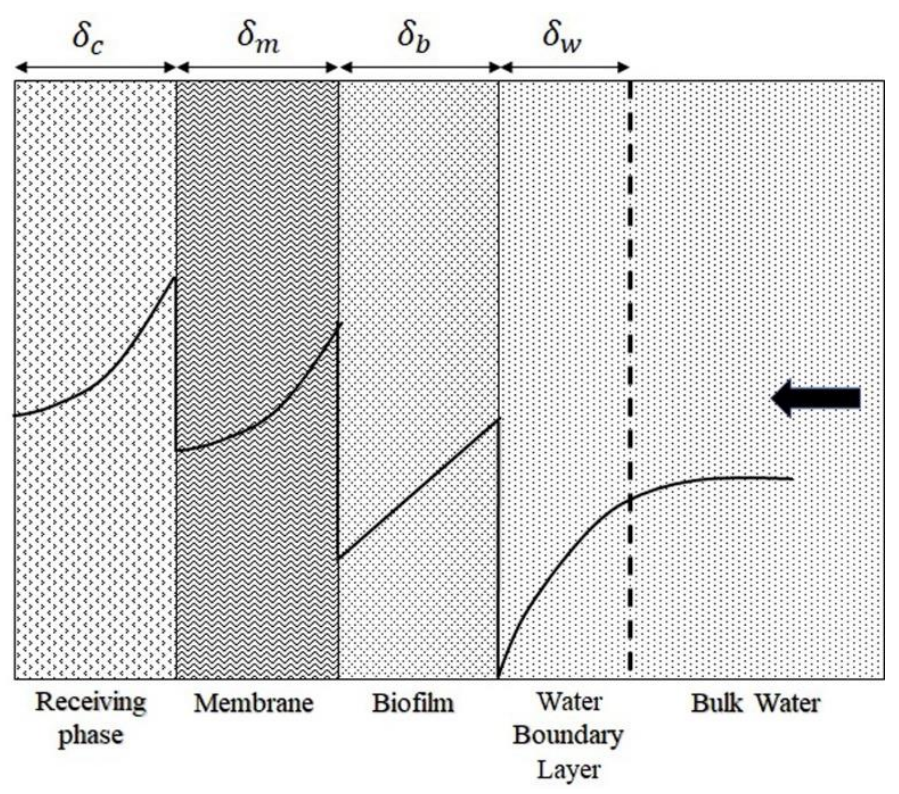

Figure 2. Schematic diagram on multi-phase transport process of pollutants in the polar organic chemical integrative sampler (POCIS) ( $\delta$ : the effective thickness of relative phases).

The enrichment process of target compounds on sorbent in the POCIS can be divided into three different regimes: (a) a linear (or kinetic/integrative) regime, (b) a pseudolinear regime, and (c) an equilibrium regime. The POCIS, as an integrative sampler, generally determines TWA concentration in a linear regime by calibrated the $R_{s}$ [39]. During a kinetic regime, the $k_{e}$ is negligible compared to the $k_{u}$, and thus Equation (1) is simplified to Equation (3):

$$
C_{s}(t)=C_{w} k_{u} t
$$

By substituting the $k_{u}$ with the sampling rate $R_{s}$, Equation (3) can be changed to an equivalent relationship, as expressed by Equation (4):

$$
C_{s}(t)=\frac{C_{w} R_{s} t}{M_{s}}
$$

The diffusion of analytes into the POCIS in an aquatic environment is a complicated mass transfer process through the WBL, biofilm, and the membrane matrix, entering the receiving absorbent (Figure 2). Under WBL control [13,34], the $R_{s}$ can be described by Equation (5):

$$
R_{s}=\left(D_{w} / \delta_{w}\right) A
$$

where $D_{w}$ is the diffusion coefficient in water; $\delta_{w}$ is the effective thickness of the WBL, and $A$ is the surface area of the sampler. Under membrane control, the $R_{S}$ can be expressed by Equation (6):

$$
R_{s}=\left(D_{m} / \delta_{m}\right) K_{m w} A
$$

where $D_{m}$ is the diffusion coefficient in the membrane and $\delta_{m}$ is the thickness of the membrane. 


\section{Influence Factors of $R_{s}$}

\subsection{Influence of Environmental Factors on $R_{S}$}

\subsubsection{Water Flow Rate}

Many studies have reported a several-fold increase in $R_{S}$ values under water turbulence state compared to those under static state [32,40-43]. The summary of $R_{s}$ values from 23 previous studies are presented in Figure 3. The further statistical analysis of data revealed a substantial positive correlation between water flow rate and the $R_{S}$ values due to the rise in diffusion rate and the decrease of WBL thickness by increasing turbulence $[13,21,26,27,41-59]$. Not surprisingly, however, a significant variability was observed in the $R_{s} /$ A values, ranging from $4.73 \times 10^{-5}$ to $1.63 \times 10^{-1} \mathrm{~L} / \mathrm{cm}^{2} / \mathrm{d}$ at flow rate from unstirring to $16.75 \mathrm{~cm} / \mathrm{s}$ since different $\mathrm{pH}$ values, various temperatures, and diverse analytes were used in the calibration experiments from the literature $[44,53,57,58]$.

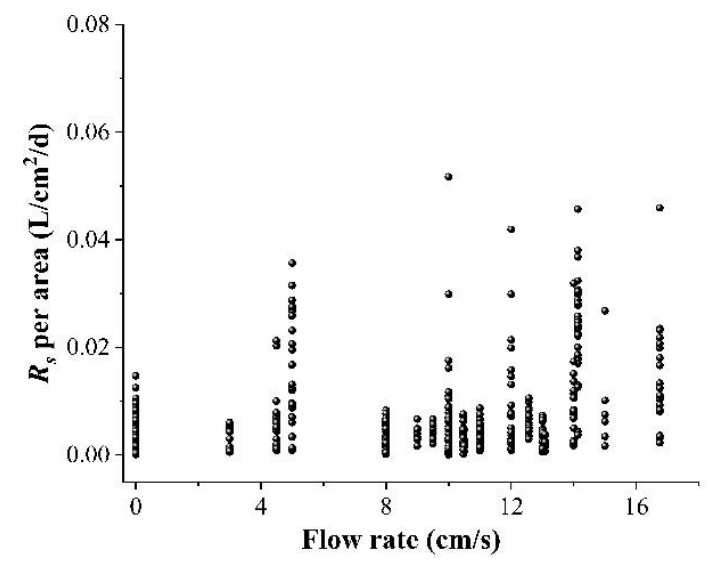

(a)

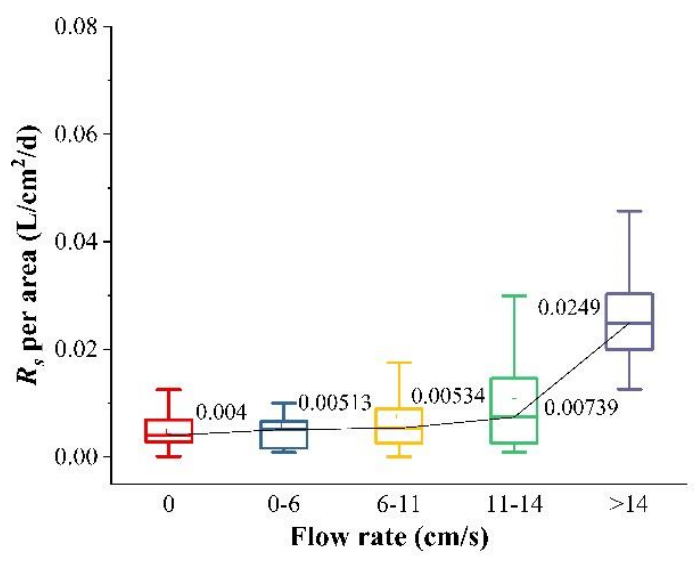

(b)

Figure 3. Summary of the $R_{S}\left(\mathrm{~L} / \mathrm{cm}^{2} / \mathrm{d}\right)$ of the POCIS determined in previous studies at different water flow rates: (a) distribution of the $R_{S}$ with water flow rate; (b) statistical analysis of the $R_{S}$ (the $R_{S}$ values were normalized to the unit surface area of the passive sampler, and the data source was from 23 previous studies).

With regard to the influence of water flow rate on the $R_{S}$ values, researchers deduced a common view that the variation of the $R_{S}$ values with flow rate is controlled by the thickness of WBL because the fixed $R_{S}$ values for different analytes were obtained at a given flow rate [60]. By considering that the total resistances to mass transfer were equivalent to the sum of the resistances for transport through the WBL, the membrane, and the sorbent, the effect of mass transfer through the WBL on the $R_{s}$ of polar organic compounds can be understood more comprehensively as it is expressed in Equation $(7)[61,62]$. When transport through the membrane was only via the pore, Equation (7) could be presented as Equation (8):

$$
\begin{gathered}
\frac{1}{k_{o}}=\frac{A}{R_{s}}=\frac{1}{k_{w}}+\frac{1}{K_{m w} k_{m}}+\frac{1}{K_{b w} k_{b}} \\
\frac{1}{k_{o}}=\frac{\delta_{w}}{D_{w}}+\frac{\delta_{m} \theta^{2}}{\Phi k_{m}}+\frac{1}{K_{b w} k_{b}}
\end{gathered}
$$

where $k_{o}$ is the overall mass transport coefficient (MTC); $k_{w}, k_{m}$, and $k_{b}$ are the MTC for the WBL, the membrane, and the biofilm, respectively; $A$ is the exposure surface area of the sampling device; $K_{m w}$ and $K_{b w}$ are the partition coefficient of the membrane water and the biofilm water, respectively; $\theta$ is the tortuosity; and $\Phi$ is the membrane porosity. It was very clear from Equations (7) and (8) that the $\delta_{w}$ value had a negative relationship with the $R_{S}$, indicating that the WBL is one of key effect factors on the $R_{S}$. 
In general, the enhanced water turbulence could cause an increase of analyte diffusion and a reduction of WBL thickness without taking account of the influence of temperature, $\mathrm{pH}$, and salinity on $R_{S}[48,63]$. Nevertheless, when the WBL thickness reduced to a certain extent, where further increase in flow rate would no longer affect the $R_{S}$ values, the components of membrane and/or pore characteristics should dominate the $R_{S}$ [55]. Numerous experiments have been carried out under laboratory conditions to explore the cumulative dynamics of samplers controlled by water membrane interface. It was found that there was a large deviation in the $R_{S}$ values obtained under in situ and laboratory conditions for the same pollutant $[26,49,52]$. This variability was mainly due to the diverse environmental conditions that have been poorly explored.

Owing to the key role of water flow rate in the mass transfer process of contaminants, it is necessary to calibrate this factor for reducing the monitoring error by POCIS, presumably through determining the difference in $R_{S}$ between quiescent and turbulent conditions and keeping the error of $R_{S}$ caused by different velocity in confidence intervals, or establishing the empirical functions of $R_{S}$ and flow rate by a large number of experiments in laboratory and in situ conditions.

\subsubsection{Temperature}

Temperature, as one of important factors in the calibration of passive samplers, plays a crucial role in the determination of the $R_{S}$. Several studies have reported that the $R_{S}$ values for some polar organic contaminants generally increased with the temperature $[27,64,65]$, although these effects were relatively small [50]. The effects of temperature on the $R_{s}$ might be associated with the solubility and mobility of analytes, the octanol-water partition coefficient $\left(K_{\text {ow }}\right)$, and the permeability of polymers in membrane [66]. Theoretically, the increase in temperature would cause an enhancement in mobility and solubility of analytes, thus facilitating the transfer of analytes from aqueous solutions to adsorbents in the POCIS. Equation (9) shows the relationship between $R_{S}$ and temperature, which can be used to calibrate the error caused by temperature effect.

$$
\ln R_{s}=\ln a-\frac{\Delta E_{a}}{\mathrm{RT}}
$$

where $R$ is the universal gas constant $(\mathrm{kJ} / \mathrm{mol} / \mathrm{K}), a$ is the pre-exponential factor expressing the maximum uptake rate at infinite temperature, $T$ is the absolute temperature $(\mathrm{K})$, and $\Delta E_{a}$ is the activation energies $(\mathrm{kJ} / \mathrm{mol})$.

On the other hand, the temperature affected the permeability of polymers, and thus determined the diffusion coefficient and solubility of analytes in polymers [67], which could be described by using Arrhenius equations:

$$
\begin{aligned}
& S=S_{0} \exp \left(-\frac{H_{s}}{\mathrm{RT}}\right) \\
& D=D_{0} \exp \left(-\frac{E_{d}}{\mathrm{RT}}\right) \\
& P=P_{0} \exp \left(-\frac{E_{p}}{\mathrm{RT}}\right)
\end{aligned}
$$

where $\mathrm{S}_{0}, \mathrm{D}_{0}$, and $\mathrm{P}_{0}$ are the standard solubility, diffusion coefficient, and permeability coefficient, respectively; $\mathrm{H}_{\mathrm{s}}$ is the heat of sorption; $\mathrm{E}_{\mathrm{d}}$ is the activation energy for diffusion; and $\mathrm{E}_{\mathrm{p}}$ is the activation energy for permeation. Through combination of Equations (10)-(12), the Ep can be expressed as Equation (13), where two parameters, Hs and Ed, depend on the net change of permeability of polymers with temperature.

$$
E_{p}=E_{d}+H_{s}
$$

It has been shown that the diffusion coefficient of analytes in the polymer polydimethylsiloxane (PDMS) increased with temperature, whereas the partition coefficient decreased with temperature [68]. 
For polymers poly(tetrafluoroethylene) (PTFE), poly(ethersulfone (PES), and polyethylene, an enhanced permeability was found with increasing temperature [69].

\subsection{3. $\mathrm{pH}$}

The solution $\mathrm{pH}$ values influenced the existing form of target compounds, further affecting their hydrophobicity, solubility, and charge properties. These physicochemical natures determined the sorption of compounds onto the adsorptive phase, thus affecting the $R_{S}$ values [70,71].

The $\mathrm{pH}$ dependence of the $R_{S}$ values was strongly related to the type of compounds. Li et al. [51] reported that the $R_{S}$ values for acidic pharmaceuticals decreased as $\mathrm{pH}$ increased from 3 to 9 , whereas those for basic compounds, such as $\beta$-blockers and anti-depressants, increased as the $\mathrm{pH}$ increased from 3 to 9 . As for the neutral drugs, e.g., carbamazepine and phenolic compounds with high ionization constant, there were no significant impacts on the $R_{S}$ values by the ambient $\mathrm{pH}$ values. Similar results were also obtained for organophosphate flame retardants (OPFRs) by Yang et al., who reported that the calculated $R_{S}$ values for the neutral molecules exhibited a slight variation in the $\mathrm{pH}$ range from 3 to 9 [72]. Therefore, due to differences in charge and physicochemical properties of the various species of a given compound, their uptake into passive sampler might differ significantly, resulting in the diverse $\mathrm{pH}$ dependence of the $R_{S}$ for various compounds [31].

\subsubsection{DOM}

The sorption of chemicals onto dissolved organic matter (DOM) was controlled by their hydrophobicity, as characterized by the $K_{o w}$ values. The partition of organic contaminant into the hydrophobic center of DOM might be through induced dipole interaction [73-75]. The presence of DOM promoted the sorption of chemicals on membrane in devices and made the mass transfer process difficult through the membrane, thus reducing the accumulation of hydrophobic organic contaminants into passive sampler [76]. The opposite conclusion has also been proposed by Charlestra et al., where the association of hydrophilic pesticides with DOM limited the sorption extent of pollutants onto the membrane surface in POCIS [77]. Moreover, several studies found that diffusive mass transfer of hydrophobic organic pollutants through the WBL could be enhanced by the presence of DOM [78,79]. These different results suggested that several factors apart from hydrophobicity influenced the $R_{s}$ values, for instance, the sorption of pharmaceuticals to DOM was driven not only by $K_{o w}$ of compounds, but also by the combined effect of DOM properties, $\mathrm{pH}$ value, and chemical properties in the sorption process [80,81]. In addition, the effect of DOM concentration on the $R_{S}$ values has been explored in several studies, where the agreed result was achieved, with little impact on $R_{s}$ values by increasing DOM concentration [51,72,77].

Given the complex structure and diverse composition of DOM, the $R_{S}$ for different pollutants are significantly diverse. Before using POCIS for monitoring chemicals, researchers should determine the effect of DOM on the device by a laboratory-field combined calibration method to obtain whether the caused error can be ignored.

\subsubsection{Salinity}

The salinity impact on the $R_{s}$ values of chemicals by the POCIS is related to the properties of the compounds, in particular to chemical groups. In general, the hydrophilicity of some organic pollutants would be reduced with the increase of salinity, affecting the partition coefficient of the pollutants. Togola et al. [64] found that with increasing salinity, the $R_{S}$ for acidic compounds exhibited subtle change, whereas for basic compounds they showed an obvious reduction. Shi et al. [32] explored the effect of salinity in the range of $0-35 \%$ on the $R_{S}$ of the POCIS, with the results showing that the maximum $R_{S}$ value was achieved at a salinity of $14 \%$.

The influence of salinity on the $R_{s}$ might be explained by the salting-out effect [82]. This effect increased with the size of the solute molecule and decreased with the polarity of the solute molecule [83]; thus, for most polar compounds in POCIS, the salting-out effect should not be statistically significant. 
Accordingly, caution should be taken in the application of freshwater-derived $R_{s}$ values to the marine environment due to the difference in partition coefficients of chemicals between membrane water in both environments $[84,85]$. Nevertheless, the impact mechanisms of salinity and the accurate salinity dependence of the $R_{s}$ value are still unknown and require more investigation.

\subsubsection{Biofouling}

When passive sampler was deployed in waterbody, biofilm layers (microorganisms, plants, algae, or animals) might be formed on the filter membrane surface, resulting in biofouling [86]. Several studies suggested that the biofouling layer could be described as the water layer with dispersed organic matter [87-89], and the mass transport coefficient $\left(k_{b}\right)$ for this layer was given as:

$$
k_{b} K_{b w}=\frac{\Phi^{2} D_{w}}{\theta \delta_{b}}
$$

where $\delta_{b}$ is the effective thickness of biofilm and other parameters referred to in Equation (8). This equation indicated that the biofilm was similar to an immobilized water layer and the $k_{b}$ value was independent on the $K_{b w}$.

The biofouling layer had an inhibitory effect on the diffusion of analyte, and thus impacted the $R_{S}$ of target analyte through an increased biofilm layer with deployed time [90]. This phenomenon might be explained by the facts that the filter membrane pores were physically clogged by biofilm [91,92] and interfacial physical-chemical reactions occurred between algae, metal oxides, dissolved substance, and the analyte on the membrane surface $[39,93]$.

Nevertheless, a different view was proposed by some researchers $[86,87,94,95]$, who showed an insignificant effect of biofouling on the $R_{S}$ for more compounds, especially for hydrophilic compounds. In those publications, the biofilm was regarded as a water layer with dispersed organic matter, and the hydrophilic compounds could permeate this layer faster.

The error of $R_{s}$ caused by biofouling can be corrected by a mathematical model (as shown in Equation (14)) simulating the impact of biofouling on the mass transfer of pollutants, as well as by performance reference compounds (PRCs) as an effective calibration method, correcting the impact of biological pollution.

\subsection{Influence of Pollutant Nature on $R_{S}$}

In previous studies, more efforts have been made to explore the correlation between $R_{S}$ values of the POCIS and $\log K_{\text {ow }}$ or logarithmic octanol-water distribution coefficient $(\log D)$ of analytes; unfortunately, no consistent results were obtained. A poor correlation between the $R_{S}$ and $\log K_{o w}$ or $\log D$ values was observed by Shaw et al. [96] and a large scattering was found by Gunold et al. [97]. Meanwhile, several researchers suggested the non-linear or linear relationship between the $R_{s}$ of POCIS and $\log K_{\text {ow }}$ or $\log D$ values [53,57,71] Those different results [51,98-100] were more likely due to the diverse functional groups of chemicals that were linked to variable trend of their hydrophobicity with alteration of solution pH values. As expressed in Equations (15) and (16) [101], the D value (representing the effective distribution of the neutral and ionic parts of compounds between octanol and water) could be adjusted according to the $\mathrm{pH}$ value of the medium, the $p K_{a}$ of the given chemical and the $K_{o w}$ values [51].

$$
\begin{aligned}
& D_{\text {Acid }}=K_{o w} /\left(1+10^{p H-p K a}\right) \\
& D_{\text {Base }}=K_{\text {ow }} /\left(1+10^{p K a-p H}\right)
\end{aligned}
$$

Therefore, Li et al. [51] found that in terms of $\mathrm{pH}$ values, the $\log D$ values decreased for acidic pharmaceuticals and increased for basic pharmaceuticals. This phenomenon revealed a positive relationship between the $R_{S}$ and $\log D$ over the $\mathrm{pH}$ range of 3-9 and the higher $R_{S}$ for neutral substances than those for ionic substances by POCIS. Using 88 polar organic micropollutants as targets to examine 
the correlation between in situ $R_{S}$ value and $\log D$, researchers found a slight linear correlation between the $R_{S}$ and $\log D$ in spite of the low regression coefficient $\left(R^{2}=0.37\right)$ and existing uncertainty. In general, polar ionic compounds with low $\log D$ had lower $R_{s}$ values than neutral ones with higher $\log D$ [100]. It was also reported that for some of pharmaceuticals and personal care products (PPCPs) and endocrine-disrupting substances (EDS) with the $\log K_{o w}$ range from 0 to 4 , there was a positive correlation between the $R_{S}$ and $\log K_{o w}$, whereas for those with $\log K_{\text {ow }}$ values higher than 4, the upward trend of the $R_{s}$ was not significant [50]. This was in agreement with Ibrahim's research, where, using a second-order polynomial function to perform a non-linear regression between the $R_{s}$ and $\log K_{\text {ow }}$ value, the author observed an increased $R_{S}$ value with the hydrophobicity for compounds with $\log K_{o w}$ range from 1.2 to 3.7 , reaching a plateau afterwards [25].

The uptake of pollutant in the integrative phase is governed by its diffusion across WBL and membrane in the POCIS [18]. The diffusion coefficient of a chemical is inversely proportional to molecular mass; thus, a negative correlation of the $R_{S}$ values with molecular mass would be expected. However, Bartelt et al. [26] performed a regression analysis to determine the relationship between molecular mass of compounds and the $R_{s}$ for the neutral compounds; unfortunately, no clear linear correlation was observed between both variables. Additionally, the data summary of the $R_{S}$ values of POCIS determined in 23 previous studies $[13,21,26,27,41-59]$ for different chemicals with various molecular mass was presented in Figure 4. As expected, a large scattering between $R_{s}$ values and molecular mass was obtained with a relative weak relationship $\left(R^{2}=0.011\right)$, which was mainly due to a combined effect of solute-sorbent-solution on the $R_{S}$ value, such as the interaction between chemical function groups of analytes and sorbents.

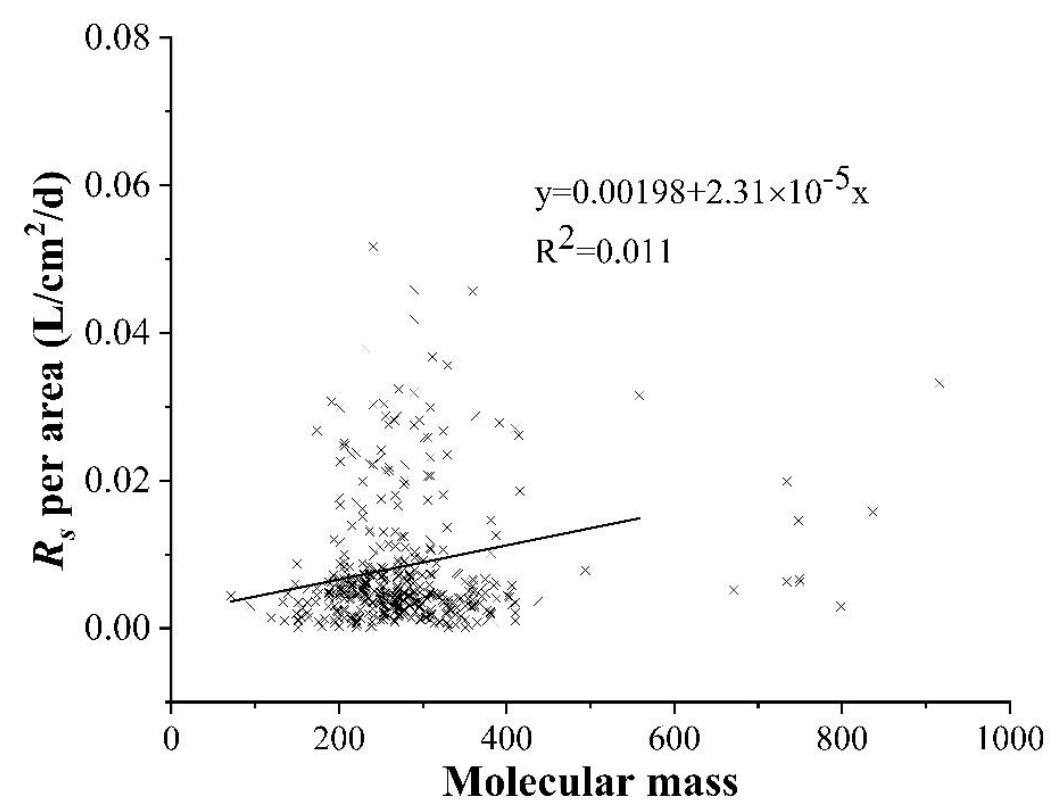

Figure 4. Summary of the $R_{S}\left(\mathrm{~L} / \mathrm{cm}^{2} / \mathrm{d}\right)$ of POCIS determined in previous studies within the range of molecular mass (the $R_{S}$ values were normalized to the surface area of the passive sampler and data source was referenced from 23 previous studies).

\subsection{Influence of Sampling Device on $R_{s}$}

\subsubsection{Membrane Properties}

The membranes used in passive sampler play a key role in hindering mass transfer of analytes and preventing direct contact of analytes with the adsorbent material during deployment. Škodová et al. [102] compared two different passive samplers for the uptake of steroid and the results showed that the chemcatcher-type sampler without diffusion-limiting PES membrane had a greater $R_{S}$ value than the POCIS. However, considering the uncertainties (such as DOM, suspended particles, 
and biofouling) caused by long-term deployment in the water environment, the POCIS with membrane could be better for monitoring trace contaminants. As a channel connecting the aqueous phase with sorbent, the exposed surface area of membrane is a crucial effect factor on the number of compounds accumulated. Zhang et al. [103] found a significant positive relationship between exposure area and the $R_{S}$ of the POCIS.

The properties of a membrane are crucial in mass transfer of the target compounds. It has been indicated that some chemicals have significant sorption onto the membrane, which results in a slow response for analyte concentrations in fluctuating aqueous phase and exhibits substantial lag times $[29,59,96,104,105]$. Satoshi and Yunosuke [106] characterized the sorption and permeation properties of membranes PES and PTFE by experimental and modelling methods. The results showed that the PES possessed strong sorption for some compounds, owing to its molecular structure with phenyl and sulfonate groups, whereas the sorption of those compounds on the PTFE was generally weak and their mass transfer was controlled by the WBL and the diffusion in membrane pore. Several sorption mechanisms, for instance, $\pi-\pi$ cloud, electrostatic, van der Waals' force (VDW), and hydrogen bonding, controlled the behavior of these compounds on both the membrane and internal surface of sorbent $[107,108]$.

\subsubsection{Sorbent}

As the enrichment phase in the sampling devices, the sorbent should not be ignored in terms of its impact on the $R_{s}[10,109]$. The hydrophilic lipophilic balance (HLB) sorbent widely used in the POCIS might adsorb hydrophilic, lipophilic, and amphiphilic molecules in different surface sites; thus, the competitive sorption appeared when different types of pollutants were enriched at the same time. The affinities of sorbent for different chemicals would affect the $R_{S}$ values $[18,110]$.

The environmental factors would also affect the distribution process of pollutants on the sorbent, for instance, the effect of $\mathrm{pH}$ was largely attributed to the increased negative potential of the Oasis HLB at higher $\mathrm{pH}$ values, leading to electrostatic repulsion/attraction [111].

\section{Measurement/Calibration of $R_{s}$}

The calibration of the $R_{S}$ usually involves the exposure of the sampler to water with a known concentration of analytes under controlled laboratory conditions, and the application of performance reference compounds (PRCs) and passive flow monitor (PFM) in field conditions [18]. Each calibration program has different data requirements.

\subsection{Laboratory Calibration}

\subsubsection{Static Depletion Design}

The design of a static depletion experiment was used to monitor a single peak of the target compounds and subsequent reduction of analyte concentration in the exposure solution [112,113]. Using first-order dissipation kinetics (Equation (1)), researchers detected, with time, the decrease of analyte concentration in water; thus, the $R_{S}$ of the passive samplers was estimated [20]. If there was no competing sorption phase (e.g., particulate or dissolved organic matter) in the exposure system and the concentration in the sampler was much lower than its equilibrium value, in a short time, Equation (1) could be converted to Equation (4) for the calibration of the $R_{S}$ [114].

This calibration method possesses specific advantages, such as simple procedure, low cost, and easy operation to alter environmental variables. It should be noted that the control experiment in this calibration had to be performed to avoid the analyte losses in the processes other than sampling accumulation. For instance, there was evidence that a large amount of analytes might have remained in the membrane $[34,59]$, which was always ignored in the calibration, causing a measurement error. 


\subsubsection{Static Renewal Design}

In this calibration mode, the samplers were deployed in a relatively small volume of exposed water, which was refreshed batchwise. To minimize the reduction of analyte concentration due to uptake into samplers during each batch exposure, the frequency for refreshing test water should be high and the solution concentration should be measured at the beginning and the end of each renewal period [29,87]. When the average aqueous concentrations did not change greatly during renewals, the uptake curve was generated, allowing for a more straightforward modelling of the $R_{s}$ by Equation (4) [71].

There are some strengths in this calibration method, such as simple operation, great feasibility to test many types of waters, and easy performance to alter environmental variable. However, this method has some disadvantages, for example, intensive exposure in water sampling and analysis, and the inability to systematically test the effects of water turbulence [112].

\subsubsection{Continuous Flow Design}

The aim of continuous flow design was to prevent depletion of aqueous solution by a continuous supply of freshly contaminated water to the exposure chamber, where multiple samplers were deployed under identical hydrodynamic conditions and the same aqueous concentration $[87,112]$. During the calibration experiment, the sorption of dissolved organic or inorganic matter should be negligible in order to avoid overestimating the concentration of analytes in solution. Stable concentrations in solution might be maintained if the flushing rate could be made up for the total sampling rate of all samplers $[16,115]$. The samplers were gradually removed from the exposure chamber, followed by eluting the sorbent to assess the $R_{s}$ of analyte. It should be noted that with decreasing sampler numbers, the flushing rate might be reduced if the hydrodynamic condition is kept constant $[65,116]$. When aqueous concentrations are maintained constant, the relationship of $R_{S}$ and $C_{s}(t)$ might be fitted by Equation (4). If aqueous concentrations are unstable, a second-order polynomial function in time (Equation (17)) could be used to describe the concentration change in sorbent [87].

$$
\frac{C_{S}(t)}{K_{m w}}=\left(C_{0}-\frac{C_{1}}{k_{e}}+\frac{2 C_{2}}{k_{e}^{2}}\right)\left[1-\exp \left(-k_{e} t\right)\right]+\left(C_{1}-\frac{2 C_{2}}{k_{e}}\right) t+C_{2} t^{2}
$$

where $C_{0}, C_{1}$, and $C_{2}$ are the constants of polynomial function.

\subsection{In Situ Calibration}

\subsubsection{Passive Flow Monitors}

Passive flow monitors (PFMs) is based on plaster dissolution that has been successfully used to assess water movement (flow and turbulence) in a field experiment [117]. At a given salinity and temperature, the loss of a specific plaster material, such as calcium sulfate, over a given surface area could be described by an empirical calibration exponent that linked the loss of plaster with the velocity and/or turbulence of the water.

As a cheap, simple, and reproducible in situ external calibration technique, PFMs have been successfully used to calibrate the $R_{s}$ of chemicals, including phosphate and polar or nonpolar herbicides and pesticides in the phosphate sampler, chemcatcher, POCIS, and SPMD [117-121]. This calibration explained the change in the $R_{s}$ with water flow velocity and ionic strength by chemical-involved and sampler-specified empirical equations, and thus the TWA concentration of chemicals could be estimated more accurately.

\subsubsection{Performance Reference Compounds}

The method using PRCs has been proposed to calibrate the $R_{s}$ values of the POCIS under in situ conditions [114]. In this calibration, the PRCs, as stable isotope compounds with similar 
physicochemical properties to the target chemicals, were pre-packed into the absorption phase in the samplers prior to deployment. The synchronization between desorption of PRCs and sorption of the target chemical was used to calculate the $R_{S}$ and concentration of target chemicals in an aquatic environment on the basis of the degree of PRC desorption [46,47,122].

For hydrophobic organic pollutants, the corresponding deuterium substitutes or ${ }^{13} \mathrm{C}$ markers (absent in the natural environment) and other substances with similar properties to targets have usually been selected for PRCs. In this case, the sorption of target compounds by receiving phase and desorption of PRCs from the absorbed phase should be in accordance with first-order kinetics [123-125]. Theoretically, the $R_{S}$ and concentration of target compound in a water environment might be calculated at any time point according to the desorption degree and the distribution coefficient of PRCs between sorbent and water [126,127]. Due to the identical interference of ambient conditions on the sorption of target compound and desorption of PRCs, the error in calibration could be reduced to a certain extent. Therefore, this quantitative method has been more widely applied in the POCIS [55,128,129]. However, many factors should be considered when applying PRCs. Firstly, the application of PRCs would increase the relative costs for sampler preparation and analysis of the obtained extracts. Secondly, the selection scope of chemicals as PRC is limited. Finally, the reproducibility obtained by loading the PRCs into the receiving phase and the possible mass loss should be taken into account by researches [119].

\subsection{In Silico Method}

The laboratory- or field-based calibration method on the $R_{s}$ would have some limitations because the alteration of diverse environment factors caused differences in the $R_{s}$ data obtained by both determination methods. Considering the time-intensive nature of experimental determination on the $R_{S}$, computational modelling methods might potentially overcome these limitations if modelling data were from the in situ calibration method and also provide a solution for the calibration of that $R_{s}$ value that cannot be estimated by field experiments due to the poor correlation between concentrations of compounds in water and on the sampling device [130].

The empirical method has been used to estimate the $R_{s}$ in some previous investigations. Stephens et al. [131] applied the dimensionless Sherwood correlation developed for the calculation of dynamic parameters in laminar flow to estimate the $R_{S}$ for some passive sampling devices. Li et al. [50] found a linear relationship $\left(R^{2}=0.84\right)$ for the laboratory-measured $R_{S}$ with a $\log K_{o w}$ of $0-4$, which could be used to predict the $R_{s}$.

In addition to the empirical method, some specific models have been increasingly applied to estimate related parameters of the $R_{S}$. Lin et al. [132], on the basis of a quantitative structure-activity relationship (QSAR) model, explored the effect of DOM on sampling dynamics. With the development of machine learning methods, the regression models can be varied from simple linear relation to complex nonlinear functions. Miller et al. [130] used artificial neural networks (ANNs) for the first time to model and predict the $R_{S}$ of organic compounds for the POCIS.

\section{Prospects}

The POCIS has been identified as the appropriate tool for investigative monitoring studies and for observing spatial and temporal distribution of polar organic compounds in water environments. However, the ongoing challenges for the POCIS should be focused on the following aspects before the POCIS becomes a reliable, robust, and cost-effective approach for many monitoring programs.

The improvement of sampling procedures should be made in the immediate future. Firstly, the biofilm would be inevitably formed in actual environmental exposures of the sampler. The formation of biofilm under field conditions caused interfacial reactions among algae, metal oxides, dissolved substance, and the analytes on biofilm. Thus, the errors in calibration of the $R_{s}$ under laboratory and field conditions would be produced due to the differences in the composition of biofilm and the physicochemical effects on the biofilm surface. To avoid biofilm formation, thereby reducing such errors in calibration of the $R_{S}$, would improve the practical application of the device. Secondly, the 
membrane has been regarded as the channel for pollutant enrichment in sampler. The physicochemical properties of membrane materials have a significant impact on the $R_{s}$. Therefore, the membrane materials should be selected and optimized to reduce the retention time of pollutants on the membrane and to enhance the adaptability of the membrane in the environment so as to improve the applicability of the device in the actual environment.

The accuracy in quantitative analysis by the POCIS should be improved. Accurate $R_{S}$ data are crucial factors for a quantitative determination of chemical by the POCIS. Calibrating the $R_{S}$ by in silico approaches could provide a new way to improve the calibration accuracy of the $R_{S}$ and reduce the uncertainty in the process of operation. Nevertheless, the reasonability of parameter selection for describing the model and the relationship between these parameters and the influence factors on the $R_{S}$ should also be further explored.

Author Contributions: Writing—original draft preparation, L.W.; writing—review and editing, R.L., X.L., H.G. All authors have read and agreed to the published version of the manuscript.

Funding: This work was supported by the Basic Scientific and Research Program for Central Nonprofit Research Institutes (no. 2017-YSKY-10) and the National Natural Science Foundation of China (no. 21277133).

Conflicts of Interest: The authors declare no conflict of interest.

\section{References}

1. Endo, S.; Matsuura, Y.; Vermeirssen, E.L. Mechanistic Model Describing the Uptake of Chemicals by Aquatic Integrative Samplers: Comparison to Data and Implications for Improved Sampler Configurations. Environ. Sci. Technol. 2019, 53, 1482-1489. [CrossRef] [PubMed]

2. Spirhanzlova, P.; Fini, J.B.; Demeneix, B.; Lardy-Fontan, S.; Vaslin-Reimann, S.; Lalere, B.; Guma, N.; Tindall, A.; Krief, S. Composition and endocrine effects of water collected in the Kibale national park in Uganda. Environ. Pollut. 2019, 251, 460-468. [CrossRef] [PubMed]

3. Taylor, A.C.; Fones, G.R.; Vrana, B.; Mills, G.A. Application of the Polar Organic Chemical Integrative Sampler for Isolation of Environmental Micropollutants-A Review. Crit. Rev. Anal. Chem. 2019, 50, 1-28. [CrossRef] [PubMed]

4. Mijangos, L.; Ziarrusta, H.; Ros, O.; Kortazar, L.; Fernandez, L.A.; Olivares, M.; Zuloaga, O.; Prieto, A.; Etxebarria, N. Occurrence of emerging pollutants in estuaries of the Basque Country: Analysis of sources and distribution, and assessment of the environmental risk. Water Res. 2018, 147, 152-163.

5. Booij, K.; Felipe, T. Passive samplers of hydrophobic organic chemicals reach equilibrium faster in the laboratory than in the field. Mar. Pollut. Bull. 2015, 98, 365-367. [CrossRef] [PubMed]

6. Zabiegała, B.; Kot-Wasik, A.; Urbanowicz, M.; Namieśnik, J. Passive sampling as a tool for obtaining reliable analytical information in environmental quality monitoring. Anal. Bioanal. Chem. 2010, 396, 273-296. [CrossRef]

7. Rico, A.; Arenas-Sanchez, A.; Alonso-Alonso, C.; Lopez-Heras, I.; Nozal, L.; Rivas-Tabares, D.; Vighi, M. Identification of contaminants of concern in the upper Tagus river basin (central Spain). Part 1: Screening, quantitative analysis and comparison of sampling methods. Sci. Total Environ. 2019, 666, 1058-1070. [CrossRef]

8. Bernard, M.; Boutry, S.; Lissalde, S.; Guibaud, G.; Saut, M.; Rebillard, J.P.; Mazzella, N. Combination of Passive and Grab Sampling Strategies Improves the Assessment of Pesticide Occurrence and Contamination Levels in a Large-Scale Watershed. Sci. Total Environ. 2019, 651, 684-695. [CrossRef]

9. Guibal, R.; Lissalde, S.; Brizard, Y.; Guibaud, G. Semi-continuous pharmaceutical and human tracer monitoring by POCIS sampling at the watershed-scale in an agricultural rural headwater river. J. Hazard. Mater. 2018, 360, 106-114. [CrossRef]

10. Vrana, B.; Mills, G.A.; Allan, I.J.; Dominiak, E.; Svensson, K.; Knutsson, J.; Morrison, G.; Greenwood, R. Passive sampling techniques for monitoring pollutants in water. Trends Anal. Chem. 2005, 24, 845-868. [CrossRef]

11. Huang, J.; Bennett, W.W.; Welsh, D.T.; Li, T.; Teasdale, P.R. Development and evaluation of adiffusive gradients in a thin film technique for measuring ammonium in freshwaters. Anal. Chim. Acta 2016, 904, 83-91. [CrossRef] [PubMed] 
12. Kingston, J.K.; Greenwood, R.; Mills, G.A.; Morrison, G.M.; Persson, L.B. Development of a novel passive sampling system for the time-averaged measurement of a range of organic pollutants in aquatic environments. J. Environ. Monit. 2000, 2, 487-495. [CrossRef] [PubMed]

13. Alvarez, D.A.; Petty, J.D.; Huckins, J.N.; Jones-Lepp, T.L.; Getting, D.T.; Goddard, J.P.; Manahan, S.E. Development of a passive, in situ, integrative sampler for hydrophilic organic contaminants in aquatic environments. Environ. Toxicol. Chem. 2004, 23, 1640-1648. [CrossRef] [PubMed]

14. Huckins, J.N.; Tubergen, M.W.; Manuweera, G.K. Semipermeable membrane devices containing model lipid: A new approach to monitoring the bioavailability of lipophilic contaminants and estimating their bioconcentration potential. Chemosphere 1990, 20, 533-552. [CrossRef]

15. Paschke, A.; Schwab, K.; Brümmer, J.; Schüürmann, G.; Paschke, H.; Popp, P. Rapid semi-continuous calibration and field test of membrane-enclosed silicone collector as passive water sampler. J. Chromatogr. A 2006, 1124, 187-195. [CrossRef]

16. Catherine, B.; Bérengère, C.; Emeline, C.; Anne, T.; Sami, B.; Philippe, M.; Laurence, A. Laboratory calibration of a POCIS-like sampler based on molecularly imprinted polymers for glyphosate and AMPA sampling in water. Anal. Bioanal. Chem. 2017, 409, 2029-2035.

17. Frank, S.L. Review of passive accumulation devices for monitoring organic micropollutants in the aquatic environment. Environ. Pollut. 2005, 136, 503-524.

18. Morin, N.; Miège, C.; Coquery, M.; Randon, J. Chemical Calibration, Performance, Validationand Applications of the Polar Organic Chemical Integrative Sampler (POCIS) in Aquatic Environments. Tractrends Anal. Chem. 2012, 36, 144-175. [CrossRef]

19. Criquet, J.; Dumoulin, D.; Howsam, M.; Mondamert, L.; Billon, G. Comparison of POCIS passive samplers vs. composite water sampling: A case study. Sci. Total Environ. 2017, 609, 982-991. [CrossRef]

20. Jorgenson, Z.G.; Thomas, L.M.; Elliott, S.M.; Cavallin, J.E.; Schoenfuss, H.L. Contaminants of emerging concern presence and adverse effects in fish: A case study in the Laurentian Great Lakes. Environ. Pollut. 2018, 236, 718-733. [CrossRef]

21. Yoonah, J.; Andreas, S.; Kilian, S. Comparison of the sampling rates and partitioning behaviour of polar and non-polar contaminants in the polar organic chemical integrative sampler and a monophasic mixed polymer sampler for application as an equilibrium passive sampler. Sci. Total Environ. 2018, 627, 905-915.

22. Muller, A.K.; Leser, K.; Kampfer, D.; Riegraf, C.; Crawford, S.E.; Smith, K.; Vermeirssen, E.L.M.; Buchinger, S.; Hollert, H. Bioavailability of Estrogenic Compounds from Sediment in the Context of Flood Events Evaluated by Passive Sampling. Water Res. 2019, 161, 540-548. [PubMed]

23. Challis, J.K.; Stroski, K.M.; Luong, K.H.; Hanson, M.L.; Wong, C.S. Field Evaluation and in Situ Stress Testing of the Organic-Diffusive Gradients in Thin-Films Passive Sampler. Environ. Sci. Technol. 2018, 52, 12573-12582. [CrossRef] [PubMed]

24. Robin, G.; Sophie, L.; Adeline, C.; Gilles, G. Improvement of POCIS ability to quantifypesticides in natural water by reducing polyethylene glycol matrix effects from polyethersulfone membranes. Talanta 2015, 144, 1316-1323.

25. Ibrahim, I.; Togola, A.; Gonzalez, C. Polar organic chemical integrative sampler (POCIS) uptake rates for 17 polar pesticides and degradation products: Laboratory calibration. Environ. Sci. Pollut. Res. Int. 2013, 20, 3679-3687. [CrossRef]

26. Bartelt-Hunt, S.L.; Snow, D.D.; Damon-Powell, T.; Brown, D.L.; Prasai, G.; Schwarz, M.; Kolok, A.S. Quantitative evaluation of laboratory uptake rates for pesticides, pharmaceuticals, and steroid hormones using POCIS. Environ. Toxicol. Chem. 2011, 30, 1412-1420. [CrossRef]

27. Yabuki, Y.; Nagai, T.; Inao, K.; Ono, J.; Aiko, N.; Ohtsuka, N.; Tanaka, H.; Tanimori, S. Temperature dependence on the pesticide sampling rate of polar organic chemical integrative samplers (POCIS). Biosci. Biotechnol. Biochem. 2016, 80, 2069-2075. [CrossRef]

28. Figueiredo, K.; Mäenpää, K.; Lyytikäinen, M.; Taskinen, J.; Leppänen, M.T. Assessing the Influence of Confounding Biological Factors When Estimating Bioaccumulation of PCBs with Passive Samplers in Aquatic Ecosystems. Sci. Total Environ. 2017, 601-602, 340-345. [CrossRef]

29. Silvani, L.; Riccardi, C.; Eek, E.; Papini, M.P.; Nao, M.; Cornelissen, G.; Amp, O.; Hale, S.E. Monitoring alkylphenols in water using the polar organic chemical integrative sampler (POCIS): Determining sampling rates via the extraction of PES membranes and Oasis beads. Chemosphere 2017, 184, 1362-1371. [CrossRef] 
30. Marion, B.; Sebastien, B.; Nathalie, T.; Héléne, B.; Nicolas, M. Lab-scale investigation of the ability of Polar Organic Chemical Integrative Sampler to catch short pesticide contamination peaks. Environ. Sci. Pollut. Res. Int. 2018, 1-11. [CrossRef]

31. Lis, H.; Stepnowski, P.; Caban, M. Salinity and $\mathrm{pH}$ as factors affecting the passive sampling and extraction of pharmaceuticals from water. J. Sep. Sci. 2019, 42, 2949-2956. [CrossRef] [PubMed]

32. Shi, X.; Zhou, J.L.; Zhao, H.; Hou, L.; Yang, Y. Application of Passive Sampling in Assessing the Occurrence and Risk of Antibiotics and Endocrine Disrupting Chemicals in the Yangtze Estuary, China. Chemosphere 2014, 111, 344-351. [CrossRef] [PubMed]

33. Djomte, V.T.; Taylor, R.B.; Chen, S.M.; Booij, K.; Chambliss, C.K. Effects of hydrodynamic conditions and temperature on polar organic chemical integrative sampling rates. Environ. Toxicol. Chem. 2018, 37, 2331-2339. [CrossRef] [PubMed]

34. Alvarez, D.A. Development of an Integrative Sampling Device for Hydrophilic Organic Contaminants in Aquatic Environments. Ph.D. Thesis, University of Missouri, Columbia, Ann Arbor, MO, USA, 1999.

35. Seethapathy, S.; Gorecki, T.; Li, X.J. Passive sampling in environmental analysis. J. Chromatogr. A 2008, 1184, 234-253. [CrossRef]

36. Salim, F.; Ioannidis, M.; Penlidis, A.; Gorecki, T. Modelling Permeation Passive Sampling: Intra-Particle Resistance to Mass Transfer and Comprehensive Sensitivity Analysis. Environ. Sci. Process. Impacts 2019, 21, 469-484. [CrossRef]

37. Huckins, J.N.; Manuweera, G.K.; Petty, J.D.; Mackay, D.; Lebo, J.A. Lipid-containing semipermeable membrane devices for monitoring organic contaminants in water. Environ. Sci. Technol. 1993, 27, 2489-2496. [CrossRef]

38. Huckins, J.N.; Petty, J.D.; Orazio, C.E.; Lebo, J.A.; Clark, R.C.; Gibson, V.L.; Gala, W.R.; Echols, K.R. Determination of Uptake Kinetics (Sampling Rates) by Lipid-Containing Semipermeable Membrane Devices (SPMDs) for Polycyclic Aromatic Hydrocarbons (PAHs) in Water. Environ. Sci. Technol. 1999, 33, 3918-3923. [CrossRef]

39. MęCzykowska, H.; Kobylis, P.; Stepnowski, P.; Caban, M. Calibration of Passive Samplers for the Monitoring of Pharmaceuticals in Water-Sampling Rate Variation. Crit. Rev. Anal. Chem. 2016. [CrossRef]

40. Vermeirssen, E.L.M.; Bramaz, N.; Hollender, J.; Singer, H.; Escher, B.I. Passive sampling combined with ecotoxicological and chemical analysis of pharmaceuticals and biocides-Evaluation of three Chemcatcher ${ }^{\mathrm{TM}}$ configurations. Water Res. 2009, 43, 903-914. [CrossRef]

41. Alvarez, D.A.; Huckins, J.N.; Petty, J.D.; Jones-Lepp, T.; Stuer-Lauridsen, F.; Getting, D.T.; Goddard, J.P.; Gravell, A. Chapter 8 Tool for monitoring hydrophilic contaminants in water: Polar organic chemical integrative sampler (POCIS). In Comprehensive Analytical Chemistry; Greenwood, R., Mills, G., Vrana, B., Eds.; Elsevier: Amsterdam, The Netherlands, 2007; Volume 48, pp. 171-197.

42. Ahrens, L.; Daneshvar, A.; Lau, A.E.; Kreuger, J. Characterization of Five Passive Sampling Devices for Monitoring of Pesticides in Water. J. Chromatogr. A 2015, 1405, 1-11. [CrossRef]

43. Martínez Bueno, M.J.; Herrera, S.; Munaron, D.; Boillot, C.; Fenet, H.; Chiron, S.; Gómez, E. POCIS passive samplers as a monitoring tool for pharmaceutical residues and their transformation products in marine environment. Environ. Sci. Pollut. Res. 2016, 23, 1-11. [CrossRef] [PubMed]

44. Bailly, E.; Levi, Y.; Karolak, S. Calibration and Field Evaluation of Polar Organic Chemical Integrative Sampler (POCIS) for Monitoring Pharmaceuticals in Hospital Wastewater. Environ. Pollut. 2013, 174, 100-105. [CrossRef] [PubMed]

45. Bayen, S.; Segovia, E.; Loh, L.L.; Burger, D.F.; Eikaas, H.S.; Kelly, B.C. Application of Polar Organic Chemical Integrative Sampler (POCIS) to Monitor Emerging Contaminants in Tropical Waters. Sci. Total Environ. 2014, 482-483, 15-22. [CrossRef] [PubMed]

46. Belles, A.; Tapie, N.; Pardon, P.; Budzinski, H. Development of the performance reference compound approach for the calibration of "polar organic chemical integrative sampler" (POCIS). Anal. Bioanal. Chem. 2014, 406, 1131-1140. [CrossRef]

47. Carpinteiro, I.; Schopfer, A.; Estoppey, N.; Fong, C.; Grandjean, D.; de Alencastro, L.F. Evaluation of performance reference compounds (PRCs) to monitor emerging polar contaminants by polar organic chemical integrative samplers (POCIS) in rivers. Anal. Bioanal. Chem. 2010, 408, 1067-1078. [CrossRef]

48. Vincent, F.; Nicolas, M.; Angel, B.; Aurélie, M.; Allan, I.J.; Hélène, B. Optimization of the polar organic chemical integrative sampler for the sampling of acidic and polar herbicides. Anal. Bioanal. Chem. 2014, 406,3191 . 
49. Vincent, F.; Nicolas, M.; Fran?Ois, D.; Karine, M.; Mélissa, E.; Hélène, B. Use of mixed-mode ion exchange sorbent for the passive sampling of organic acids by polar organic chemical integrative sampler (POCIS). Environ. Sci. Technol. 2012, 46, 13344-13353.

50. Li, H.; Helm, P.A.; Metcalfe, C.D. Sampling in the Great Lakes for pharmaceuticals, personal care products, and endocrine-disrupting substances using the passive polar organic chemical integrative sampler. Environ. Toxicol. Chem. 2010, 29, 751-762. [CrossRef]

51. Li, H.; Helm, P.A.; Gordon, P.; Metcalfe, C.D. The effects of dissolved organic matter and pH on sampling rates for polar organic chemical integrative samplers (POCIS). Chemosphere 2011, 83, 271-280. [CrossRef]

52. Mirasole, C.; Di, C.M.; Tanwar, S.; Magi, E. Liquid chromatography-tandem mass spectrometry and passive sampling: Powerful tools for the determination of emerging pollutants in water for human consumption. J. Mass Spectrom. 2016, 51, 814-820. [CrossRef]

53. Macleod, S.L.; Mcclure, E.L.; Wong, C.S. Laboratory calibration and field deployment of the polar organic chemical integrative sampler for pharmaceuticals and personal care products in wastewater and surface water. Environ. Toxicol. Chem. 2010, 26, 2517-2529. [CrossRef] [PubMed]

54. Mazzella, N.; Dubernet, J.-F.o.; Delmas, F.o. Determination of kinetic and equilibrium regimes in the operation of polar organic chemical integrative samplers: Application to the passive sampling of the polar herbicides in aquatic environments. J. Chromatogr. A 2007, 1154, 42-51. [CrossRef] [PubMed]

55. Miège, C.; Budzinski, H.; Jacquet, R.; Soulier, C.; Pelte, T.; Coquery, M. Polar organic chemical integrative sampler (POCIS): Application for monitoring organic micropollutants in wastewater effluent and surface water. J. Environ. Monit. 2012, 14, 626-635. [CrossRef] [PubMed]

56. Lissalde, S.; Mazzella, N.; Fauvelle, V.; Delmas, F.; Mazellier, P.; Legube, B. Liquid chromatography coupled with tandem mass spectrometry method for thirty-three pesticides in natural water and comparison of performance between classical solid phase extraction and passive sampling approaches. J. Chromatogr. A 2011, 1218, 1492-1502. [CrossRef] [PubMed]

57. Morin, N.; Camilleri, J.; Cren-Olivé, C.; Coquery, M.; Miège, C. Determination of uptake kinetics and sampling rates for 56 organic micropollutants using "pharmaceutical" POCIS. Talanta 2013, 109, 61-73. [CrossRef]

58. Thomatou, A.A.; Antonopoulou, M.; Michail, F.; Konstantinou, I. Laboratory calibration of twelve pesticides using polar organic chemical integrative samplers. Int. J. Environ. Anal. Chem. 2015, 95, 1230-1241. [CrossRef]

59. Vermeirssen, E.L.; Dietschweiler, C.; Escher, B.I.; Van, d.V.J.; Hollender, J. Transfer Kinetics of Polar Organic Compounds over Polyethersulfone Membranes in the Passive Samplers Pocis and Chemcatcher. Environ. Sci. Technol. 2012, 46, 6759-6766. [CrossRef]

60. Chen, C.E.; Zhang, H.; Ying, G.G.; Jones, K.C. Evidence and recommendations to support the use of a novel passive water sampler to quantify antibiotics in wastewaters. Environ. Sci. Technol. 2013, 47, 13587-13593. [CrossRef]

61. Booij, K.; Maarsen, N.L.; Theeuwen, M.; Bommel, R.V. A method to account for the effect of hydrodynamics on polar organic compound uptake by passive samplers. Environ. Toxicol. Chem. 2017, 36, 1517-1524. [CrossRef]

62. Fauvelle, V.; Kaserzon, S.L.; Montero, N.; Lissalde, S.; Allan, I.J.; Mills, G.; Mazzella, N.; Mueller, J.F.; Booij, K. Dealing with Flow Effects on the Uptake of Polar Compounds by Passive Samplers. Environ. Sci. Technol. 2017, 51, 2536-2537. [CrossRef]

63. Söderström, H.; Lindberg, R.H.; Fick, J. Strategies for monitoring the emerging polar organic contaminants in water with emphasis on integrative passive sampling. J. Chromatogr. A 2009, 1216, 623-630. [CrossRef] [PubMed]

64. Togola, A.; Budzinski, H. Development of polar organic integrative samplers for analysis of pharmaceuticals in aquatic systems. Anal. Chem. 2007, 79, 6734-6741. [CrossRef] [PubMed]

65. Booij, K.; Hofmans, H.E.; Fischer, C.V.; Weerlee, E.M.V. Temperature-dependent uptake ratesof nonpolar organic compounds by semipermeable membrane devices and low-density polyethylene membranes. Environ. Sci. Technol. 2003, 37, 361-366. [CrossRef] [PubMed]

66. Tang, J.F.; Chen, S.; Xu, Y.P.; Zhong, W.J.; Ma, M.; Wang, Z.J. Calibration and Field Performance of Triolein Embedded Acetate Membranes for Passive Sampling Persistent Organic Pollutants in Water. Environ. Pollut. 2012, 164, 158-163. [CrossRef] [PubMed]

67. Delle Site, A. Factors affecting sorption of organic compounds in natural sorbent/water systems and sorption coefficients for selected pollutants. A review. J. Phys. Chem. Ref. Data 2001, 30, 187-439. [CrossRef] 
68. Simonetta, T.; Luc, V.; Jean-Francois, G.; Pierre-Charles, M. Thermogravimetric calibration of permeation tubes used for the preparation of gas standards for air pollution analysis. Analyst 2005, 130, 1369-1374.

69. Klopffer, M.H.; Flaconneche, B. Transport properties of gases in polymers: Bibliographic review. Oil Gas Sci. Technol. Rev. D Ifp Energ. Nouv. 2001, 56, 223-244. [CrossRef]

70. Wong, C.S.; Macleod, S.L. JEM spotlight: Recent advances in analysis of pharmaceuticals in theaquatic environment. J. Environ. Monit. 2009, 11, 923-936. [CrossRef]

71. Thomatou, A.-A.; Zacharias, I.; Hela, D.; Konstantinou, I. Passive sampling of selected pesticides in aquatic environment using polar organic chemical integrative samplers. Environ. Sci. Pollut. Res. 2011, 18, 1222-1233. [CrossRef]

72. Yang, C.M.; Li, Y.; Zha, D.P.; Lu, G.H.; Sun, Q.; Wu, D.H. A passive sampling method for assessing the occurrence and risk of organophosphate flame retardants in aquatic environments. Chemosphere 2017, 167, 1-9. [CrossRef]

73. Dunnivant, F.M.; Anders, E. Case Studies of Selected Pollutants. In A Basic Introduction to Pollutant Fate and Transport: An Integrated Approach with Chemistry, Modeling, Risk Assessment, and Environmental Legislation; John Wiley \& Sons, Ltd.: Hoboken, NJ, USA, 2006; pp. 397-418. [CrossRef]

74. Lam, B.; Simpson, A.J. Passive sampler for dissolved organic matter in freshwater environments. Anal. Chem. 2006, 78, 8194. [CrossRef] [PubMed]

75. Jermann, D.; Pronk, W.; Boller, M.; Schaefer, A.I. The role of NOM fouling for the retention of estradiol and ibuprofen during ultrafiltration. J. Membr. Sci. 2009, 329, 75-84. [CrossRef]

76. Gourlay, C.; Miège, C.; Noir, A.; Ravelet, C.; Garric, J.; Mouchel, J.-M. How accurately do semi-permeable membrane devices measure the bioavailability of polycyclic aromatic hydrocarbons to Daphnia magna? Chemosphere 2005, 61, 1734-1739. [CrossRef] [PubMed]

77. Charlestra, L.; Amirbahman, A.; Courtemanch, D.L.; Alvarez, D.A.; Patterson, H. Estimating pesticide sampling rates by the polar organic chemical integrative sampler (POCIS) in the presence of natural organic matter and varying hydrodynamic conditions. Environ. Pollut. 2012, 169, 98-104. [CrossRef]

78. Wang, L.; Gong, X.Y.; Wang, R.N.; Gan, Z.W.; Lu, Y.; Sun, H.W. Application of an Immobilized Ionic Liquid for the Passive Sampling of Perfluorinated Substances in Water. J. Chromatogr. A 2017, 1515, 45-53. [CrossRef]

79. Li, Y.; Yang, C.M.; Bao, Y.J.; Ma, X.R.; Lu, G.H.; Li, Y. Aquatic Passive Sampling of Perfluorinated Chemicals with Polar Organic Chemical Integrative Sampler and Environmental Factors Affecting Sampling Rate. Environ. Sci. Pollut. Res. Int. 2016, 23, 1-8. [CrossRef]

80. Nikolaou, A.; Meric, S.; Fatta, D. Occurrence patterns of pharmaceuticals in water and wastewater environments. Anal. Bioanal. Chem. 2007, 387, 1225. [CrossRef]

81. Lilia, A.; Noreiva, V.; Nuris, C.; Maikellys, B.; Theobaldo, G.; Avismelsi de Jesus, P. Persistence of gemfibrozil, naproxen and mefenamic acid in natural waters. Environ. Chem. Lett. 2011, 9, 13-18.

82. Jonker, M.T.O.; Muijs, B. Using solid phase micro extraction to determine salting-out (Setschenow) constants for hydrophobic organic chemicals. Chemosphere 2010, 80, 223-227. [CrossRef]

83. Satoshi, E.; Andrea, P.; Kai-Uwe, G. Salting-out effect in aqueous $\mathrm{NaCl}$ solutions: Trends with size and polarity of solute molecules. Environ. Sci. Technol. 2012, 46, 1496-1503.

84. Sacks, V.P.; Rainer, L. Development and use of polyethylene passive samplers to detect triclosans and alkylphenols in an urban estuary. Environ. Sci. Technol. 2011, 45, 2270-2277. [CrossRef] [PubMed]

85. Jonker, M.T.O.; Van Der Heijden, S.A.; Marcel, K.; Foppe, S. Quantifying the effects of temperature and salinity on partitioning of hydrophobic organic chemicals to silicone rubber passive samplers. Environ. Sci. Technol. 2015, 49, 6791-6799. [CrossRef] [PubMed]

86. Richardson, B.J.; Lam, P.K.S.; Zheng, G.J.; Mcclellan, K.E.; De, L.-A.S.B. Biofouling Confounds the Uptake of Trace Organic Contaminants by Semi-Permeable Membrane Devices (SPMDs). Mar. Pollut. Bull. 2002, 44, 1372-1379. [CrossRef]

87. Kees, B.; Vrana, B.; Huckins, J.N. Chapter 7 Theory, Modelling and Calibration of Passive Samplers Used in Water Monitoring. In Comprehensive Analytical Chemistry; Greenwood, R., Mills, G., Vrana, B., Eds.; Elsevier: Amsterdam, The Netherlands, 2007; Volume 48, pp. 141-169.

88. Polidoro, B.A.; Morra, M.J.; Clemens, R.; Luisa Eugenia, C. Pesticide sequestration in passive samplers (SPMDs): Considerations for deployment time, biofouling, and stream flow in a tropical watershed. J. Environ. Monit. 2009, 11, 1866-1874. [CrossRef] 
89. Rosen, G.; Lotufo, G.R.; George, R.D.; Wild, B.; Rabalais, L.K.; Morrison, S.; Belden, J.B. Field validation of POCIS for monitoring at underwater munitions sites. Environ. Toxicol. Chem. 2018, 37, 2257-2267. [CrossRef]

90. Flemming, H.C.; Schaule, G.; Griebe, T.; Schmitt, J.; Tamachkiarowa, A. Biofouling-The Achilles Heel of Membrane Processes. Desalination 1997, 113, 215-225. [CrossRef]

91. Lissalde, S.; Mazzella, N.; Mazellier, P. Polar organic chemical integrative samplers for pesticides monitoring: Impacts of field exposure conditions. Sci. Total Environ. 2014, 488-489, 188-196. [CrossRef]

92. Stéphane, P.; Soizic, M.; Sophie, L.; Bernard, M.; Nicolas, M. Combining polar organic chemical integrative samplers (POCIS) with toxicity testing to evaluate pesticide mixture effects on natural phototrophic biofilms. Environ. Pollut. 2011, 159, 735-741.

93. Feng, Z.; Zhu, P.; Fan, H.; Piao, S.; Xu, L.; Sun, T. Effect of Biofilm on Passive Sampling of Dissolved Orthophosphate Using the Diffusive Gradients in Thin Films Technique. Anal. Chem. 2016, 88, 6836-6843. [CrossRef]

94. Booij, K.; Bommel, R.V.; Mets, A.; Dekker, R. Little effect of excessive biofouling on the uptake of organic contaminants by semipermeable membrane devices. Chemosphere 2006, 65, 2485-2492. [CrossRef]

95. Ralf Bernhard, S.; Albrecht, P.; Matthias, L. Aquatic Passive Sampling of a Short-Term Thiacloprid Pulse with the Chemcatcher: Impact of Biofouling and Use of a Diffusion-Limiting Membrane on the Sampling Rate. J. Chromatogr. A 2008, 1203, 1-6.

96. Shaw, M.; Eaglesham, G.; Mueller, J.F. Uptake and release of polar compounds in SDB-RPS Empore ${ }^{\mathrm{TM}}$ disks; $^{\circ}$ implications for their use as passive samplers. Chemosphere 2009, 75, 1-7. [CrossRef] [PubMed]

97. Gunold, R.; Schäfer, R.B.; Paschke, A.; Schüürmann, G.; Liess, M. Calibration of the Chemcatcher ${ }^{\circledR}$ : Passive Sampler for Monitoring Selected Polar and Semi-Polar Pesticides in Surface Water. Environ. Pollut. 2008, 155, 52-60. [CrossRef] [PubMed]

98. Li, H.; Vermeirssen, E.L.; Helm, P.A.; Metcalfe, C.D. Controlled field evaluation of water flow rate effects on sampling polar organic compounds using polar organic chemical integrative samplers. Environ. Toxicol. Chem. 2010, 29, 2461-2469. [CrossRef]

99. Vermeirssen, E.L.M.; Conrad, D.; Escher, B.I.; Van Der Voet, J.; Juliane, H. Uptake and release kinetics of 22 polar organic chemicals in the Chemcatcher passive sampler. Anal. Bioanal. Chem. 2013, 405, 5225-5236. [CrossRef] [PubMed]

100. Moschet, C.; Vermeirssen, E.L.M.; Singer, H.; Stamm, C.; Hollender, J. Evaluation of in-situ calibration of Chemcatcher passive samplers for 322 micropollutants in agricultural and urban affected rivers. Water Res. 2015, 71, 306-317. [CrossRef]

101. Magnér, J.A.; Alsberg, T.E.; Broman, D. Bag-SPE—A Convenient Extraction Method for Screening of Pharmaceutical Residues in Influent and Effluent Water from Sewage Treatment Plants. Anal. Bioanal. Chem. 2009, 395, 1481-1489. [CrossRef]

102. Škodová, A.; Prokeš, R.; Šimek, Z.; Vrana, B. In situ calibration of three passive samplers for the monitoring of steroid hormones in wastewater. Talanta 2016, 161, 405-412. [CrossRef]

103. Zhang, Z.L.; Hibberd, A.; Zhou, J.L. Analysis of Emerging Contaminants in Sewage Effluent and River Water: Comparison between Spot and Passive Sampling. Anal. Chim. Acta 2008, 607, 37-44. [CrossRef]

104. Petrie, B.; Gravell, A.; Mills, G.A.; Youdan, J.; Barden, R.; Kasprzyk-Hordern, B. In Situ Calibration of a New Chemcatcher Configuration for the Determination of Polar Organic Micropollutants in Wastewater Effluent. Environ. Sci. Technol. 2016, 50, 9469-9478. [CrossRef]

105. Estoppey, N.; Mathieu, J.; Diez, E.G.; Sapin, E.; Delemont, O.; Esseiva, P.; de Alencastro, L.F.; Coudret, S.; Folly, P. Monitoring of explosive residues in lake-bottom water using Polar Organic Chemical Integrative Sampler (POCIS) and chemcatcher: Determination of transfer kinetics through Polyethersulfone (PES) membrane is crucial. Environ. Pollut. 2019, 252, 767-776. [CrossRef] [PubMed]

106. Satoshi, E.; Yunosuke, M. Characterizing Sorption and Permeation Properties of Membrane Filters Used for Aquatic Integrative Passive Samplers. Environ. Sci. Technol. 2018, 52, 2118-2125.

107. Djomte, V.T.; Chen, S.; Chambliss, C.K. Effects of suspended sediment on POCIS sampling rates. Chemosphere 2019, 241, 124972. [CrossRef] [PubMed]

108. Galle, T.; Koehler, C.; Plattes, M.; Pittois, D.; Bayerle, M.; Carafa, R.; Christen, A.; Hansen, J. Large-scale determination of micropollutant elimination from municipal wastewater by passive sampling gives new insights in governing parameters and degradation patterns. Water Res. 2019, 160, 380-393. 
109. Harman, C.; Brooks, S.; Sundt, R.C.; Meier, S.; Grung, M. Field comparison of passive sampling and biological approaches for measuring exposure to $\mathrm{PAH}$ and alkylphenols from offshore produced water discharges. Mar. Pollut. Bull. 2011, 63, 141-148. [CrossRef]

110. Gobelius, L.; Persson, C.; Wiberg, K.; Ahrens, L. Calibration and Application of Passive Sampling for Per and Polyfluoroalkyl Substances in a Drinking Water Treatment Plant. J. Hazard. Mater. 2019, 362, 230-237. [CrossRef]

111. Jeong, Y.; Schäffer, A.; Smith, K. Equilibrium partitioning of organic compounds to OASIS HLB ${ }^{\circledR}$; as a function of compound concentration, $\mathrm{pH}$, temperature and salinity. Chemosphere 2017, 174, 297-305. [CrossRef]

112. Harman, C.; Allan, I.J.; Vermeirssen, E.L.M. Calibration and Use of the Polar Organic Chemical Integrative Sampler-a Critical Review. Environ. Toxicol. Chem. 2012, 31, 2724-2738. [CrossRef]

113. Jeong, Y.; Schaffer, A.; Smith, K. A comparison of equilibrium and kinetic passive sampling for the monitoring of aquatic organic contaminants in German rivers. Water Res. 2018, 145, 248-258. [CrossRef]

114. Brophy, M.J.; Mackie, A.L.; Park, Y.; Gagnon, G.A. Exploring the detection of microcystin-LR using polar organic chemical integrative samplers (POCIS). Environ. Sci. Process. Impacts 2019, 21, 659-666. [CrossRef]

115. Mijangos, L.; Ziarrusta, H.; Prieto, A.; Zugazua, O.; Zuloaga, O.; Olivares, M.; Usobiaga, A.; Paschke, A.; Etxebarria, N. Evaluation of polar organic chemical integrative and hollow fibre samplers for the determination of a wide variety of organic polar compounds in seawater. Talanta 2018, 185, 469-476. [CrossRef] [PubMed]

116. Ouyang, G.F.; Chen, Y.; Pawliszyn, J. Flow-through system for the generation of standard aqueous solution of polycyclic aromatic hydrocarbons. J. Chromatogr. A 2006, 1105, 176-179. [CrossRef] [PubMed]

117. O'Brien, D.S.; Barry, C.; Mueller, J.F. A novel method for the in situ calibration of flow effects on a phosphate passive sampler. J. Environ. Monit. 2008, 11, 212-219.

118. O'Brien, D.S.; Kees, B.; Hawker, D.W.; Mueller, J.F. Method for the in situ calibration of a passive phosphate sampler in estuarine and marine waters. Environ. Sci. Technol. 2011, 45, 2871-2877. [CrossRef] [PubMed]

119. O'Brien, D.S.; Michael, B.; Mueller, J.F. Determination of deployment specific chemical uptake rates for SDB-RPD Empore disk using a passive flow monitor (PFM). Chemosphere 2011, 83, 1290-1295. [CrossRef]

120. Kaserzon, S.L.; Hawker, D.W.; Booij, K.; O’Brien, D.S.; Kennedy, K.; Vermeirssen, E.L.M.; Mueller, J.F. Passive sampling of perfluorinated chemicals in water: In-situ calibration. Environ. Pollut. 2014, 186, 98-103. [CrossRef]

121. Novic, A.J.; O'Brien, D.S.; Kaserzon, S.L.; Hawker, D.W.; Lewis, S.E.; Mueller, J.F. Monitoring Herbicide Concentrations and Loads during a Flood Event: A Comparison of Grab Sampling with Passive Sampling. Environ. Sci. Technol. 2017, 51, 3880-3891. [CrossRef]

122. Huckins, J.N.; Petty, J.D.; Lebo, J.A.; Almeida, F.V.; Booij, K.; Alvarez, D.A.; Cranor, W.L.; Clark, R.C.; Mogensen, B.B. Development of the permeability/performance reference compound approach for in situ calibration of semipermeable membrane devices. Environ. Sci. Technol. 2002, 36, 85-91. [CrossRef]

123. Tomaszewski, J.E.; Luthy, R.G. Field deployment of polyethylene devices to measure PCB concentrations in pore water of contaminated sediment. Environ. Sci. Technol. 2008, 42, 6086-6091. [CrossRef]

124. Tran, A.T.K.; Hyne, R.V.; Doble, P. Calibration of a Passive Sampling Device for Time-Integrated Sampling of Hydrophilic Herbicides in Aquatic Environments. Environ. Toxicol. Chem. 2010, 26, 435-443. [CrossRef]

125. Li, Y.; Yao, C.; Zha, D.P.; Yang, W.; Lu, G.H. Selection of performance reference compound (PRC) for passive sampling of pharmaceutical residues in an effluent dominated river. Chemosphere 2018, 211, 884-892. [CrossRef] [PubMed]

126. Vrana, B.; Mills, G.A.; Kotterman, M.; Leonards, P.; Booij, K.; Greenwood, R. Modelling and field application of the Chemcatcher passive sampler calibration data for the monitoring of hydrophobic organic pollutants in water. Environ. Pollut. 2007, 145, 895-904. [CrossRef] [PubMed]

127. Liu, H.H.; Wong, C.S.; Zeng, E.Y. Recognizing the limitations of performance reference compound (PRC)-calibration technique in passive water sampling. Environ. Sci. Technol. 2013, 47, 10104-10105. [CrossRef] [PubMed]

128. Harman, C.; Reid, M.; Thomas, K.V. In situ calibration of a passive sampling device for selected illicit drugs and their metabolites in wastewater, and subsequent year-long assessment of community drug usage. Environ. Sci. Technol. 2011, 45, 5676-5682. [CrossRef] [PubMed]

129. Harman, C.; Allan, I.J.; Bauerlein, P.S. The Challenge of Exposure Correction for Polar Passive Samplers-The PRC and the POCIS. Environ. Sci. Technol. 2011, 45, 9120-9121. [CrossRef] 
130. Miller, T.H.; Baz-Lomba, J.A.; Harman, C.; Reid, M.J.; Owen, S.F.; Bury, N.R.; Thomas, K.V.; Barron, L.P. The First Attempt at Non-Linear in Silico Prediction of Sampling Rates for Polar Organic Chemical Integrative Samplers (POCIS). Environ. Sci. Technol. 2016, 50, 7973-7981. [CrossRef]

131. Stephens, B.S.; Kapernick, A.; Eaglesham, G.; Mueller, J. Aquatic passive sampling of herbicides on naked particle loaded membranes: Accelerated measurement and empirical estimation of kinetic parameters. Environ. Sci. Technol. 2005, 39, 8891-8897. [CrossRef]

132. Lin, W.; Jiang, R.; Shen, Y.; Xiong, Y.; Hu, S.; Xu, J.; Ouyang, G. Effect of dissolved organic matter on pre-equilibrium passive sampling: A predictive QSAR modeling study. Sci. Total Environ. 2018, 635, 53-59. [CrossRef]

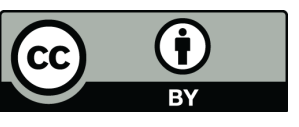

(C) 2020 by the authors. Licensee MDPI, Basel, Switzerland. This article is an open access article distributed under the terms and conditions of the Creative Commons Attribution (CC BY) license (http://creativecommons.org/licenses/by/4.0/). 